\title{
TRANSFORMATIONS IN THE POLISH-GERMAN-CZECH BORDER AREA IN 1938-1945 IN THE LOCAL COLLECTIVE MEMORY AND SOCIAL AWARENESS OF THE INHABITANTS OF BIELAWA AND THE OWL MOUNTAINS AREA
}

Jaromir JESZKE

\section{ABSTRACT}

The local community of Bielawa and the areas in the region of the Owl Mountains is an interesting object for studies of sites of memory represented in local consciousness. Like most of similar communities on the so-called Recovered Territories, it started to form after 1945 on "raw roots" after the German inhabitants of the area were removed. They were replaced with people moved from the former eastern provinces of the Second Republic, among others from Kołomyja, but also from regions of central Poland. Also Poles returning from Germany, France and Romania settled there. The area taken over by new settlers had not been a cultural desert. The remains of material culture, mainly German, and the traditions of weaving and textile industry, reaching back to the Middle Ages, formed a huge potential for creating a vision of local cultural heritage for the newly forming community. They also brought, however, their own notions of cultural heritage to the new area and, in addition, became subject to political pressure of recognising its "Piast" character as the "Recovered Territories". The present research is an attempt to find out to what extent that potential was utilised by new settlers, who were carriers of various regional (or even national) cultures, for their creation of visions of the future, as well as how the dynamics of those transformations evolved.

\section{KEYWORDS:}


The local community of Bielawa (Ger. Langenbielau) and the Owl Mountains region seems to be an interesting subject of research on the sites of memory present in the local awareness. Like most similar communities in the so-called Recovered Territories, it has been taking shape since 1945 from scratch, once the German population was deported. They were replaced by people displaced from the Eastern Borderlands of the Second Polish Republic, including Kolomiya, and central Poland, as well as Poles from Germany, France, and Romania. As noted by the chronicler of Bielawa Krzysztof Pludro, "the main mass of settlers in Bielawa was composed of Poles from various parts of central Poland, then those from beyond the Bug River, that is, the lost Eastern Borderlands (Lviv, Volhynia, Vilnius), followed by repatriates from the USSR and Western countries, mainly Germany, France, as well as the Romanian Bucovina. (...) There were only relatively few cases when the settlers came in wellorganised groups and created a new homogeneous neighbour society. (...) For a long time, all these groups mostly held to their own traditional cultural forms, displaying fairly significant differences in lifestyle, language forms, attitudes to life, traditions, and social norms." 1 Groups of Jews, and after 1949 Greek emigrants too, added to this cultural diversity of the new settlers. The former group in particular was economically very active. One should also add to this a small number of German nationals and 'indigenes', or people declaring their affiliation to the Polish nation who lived in Bielawa since World War I, and sometimes for generations.

This mosaic of populations of various regional and national origins could not immediately become a community with developed attitudes toward the memory of the past. These groups were divided not only by their stance on the past but also their attitude to oher cultural layers, sometimes divergent economic and social agendas, and political views. The shattered and displaced community of old Bielawa was not replaced by a new one. It took the culturally varied groups several decades to make up a local society. Early in this process, the variety of views of the past brought in by the settlers inhibited the creation of a coherent local community. The inhabitants of Bielawa, as its chronicler noted, were a gathering of culturally highly distinct small groups and individuals. Occasional meetings with the German populace being displaced was the sole thin thread tying them to the town's past. While it may have been impossible to ignore the vanishing presence of the old dwellers due to these encounters, which were more of a conflict than reflection upon the past due to the taking over of their belongings. However, the small group of Germans and 'indigenes' left in Bielawa could not significantly affect the nature of these relations. The beginning of the formation of

${ }^{1}$ K. Pludro, Kronika Bielawy. Część V. Lata 1945-1990 [Chronicle of Bielawa: Part V: 1945-1990], Dzierżoniów 2002 , p. 30. 
the new local community abounded in many contradictions present both among the immigrant population and the remaining German inhabitants of Bielawa.

The area claimed by the settlers had not been a cultural wasteland. The remnants of mostly German material culture and traditions of weaving and textile industry, going back to the middle ages, provided much potential there to create an image of a local cultural heritage of the newly forming community. In the first stages of the formation of this community, however, this cultural potential could not be used, for the settlers brought to the newly claimed areas their own cultural patterns and conceptions of cultural heritage, including material culture, different from what they found. They were also under political pressure to accept its 'Piast' nature of 'Recovered Territories.' The national view of the past comprised of exclusively Polish cultural heritage, justifying the rights to the so-called Recovered Territories, purposely condemned the achievements of other nations to oblivion. Cultivating the memory of the local, German cultural heritage was but an obstacle in the construciton of politically desirable image of the past.

Small groups of Germans and 'indigenes' were the fragile connection with the culture of the displaced inhabitants. However, their visions of cultural heritage were but one, and by no means predominant, component of the cultural mosaic sketched here. The mosaic itself was also changing, as the cultural substrates of the weakest groups (German, 'indigenous', Jewish, and Greek) decreased with the passing years. The adaptation to the new conditions of various human groups which did not immediately combine into a coherent community was initially aimed more at the future, leaving reflections upon the past behind. Still, the past was bound to the every-day life of the arrivals via the textile plants they took over, mainly from the Dierga family, which was the largest employer of the population living in the Owl Mountains area. Here, the contact with German employees was inevitable, as well as with their cultural attitudes. These cultural encounters however, as Bielawa was being left by more and more German specialists, played an increasingly minor role in the analysed process. There was less and less of an impulse to reflect on the past of Bielawa.

The main thread of this study is to analysie the use of the local potential of the existing heritage by new settlers, who were carriers of various regional, sometimes national cultures, in the construction of visions of the past in the context of the new community formation processes occurring in Bielawa. The changes taking place over time were also the result of small groups of German, Jewish, and later also Greek population leaving Bielawa, and the formation of a local community composed from Polish nationals arrived from various parts of Poland and Europe. Nonetheless, 
the normalisation of Polish-German relations in the 1970s made sentimental journeys of the former inhabitants of Bielawa to their homeland possible, which served to activate the memory of the past before 1945 . These cultural complications shaping the memory of the past should also include the state's historical policy at the time, which actively sought historical justifications for the accession of the western and northern territories to Poland. It is in this complex configuration of cultural, social, and political factors that one should discuss the sites of memory, in the awareness of the inhabitants, associated with the culture of the previous inhabitants of this land, and their readiness to include its memory to the regional heritage. The following questions should be analysed in the context of the local community accepting the cultural heritage, including that of the people who lived in this area before 1945, as its own:

- what sense and meaning were attached to a certain event, person, or place?

- what was remembered/forgotten?

- what is suppressed from memory?

- what is being used instrumentally?

- what is being appropriated by generations, institutions, and social groups?

The answers to each of these questions changed in various periods of history along with the changing economic, social, and political conditions of life of the studied local community since 1946. In this scope, the source of the changes occurring in the social awareness is the attitude of the studied inhabitants of Bielawa and its environs towards to the population changes in the German-Polish-Czech border area in 1938-1946. The sites of collective memory, whose configuration has been changing constantly since 1946, can be summarised as follows:

- regional sites of memory, like the sites of memory of the Owl Mountains area and 'post-German' sites;

- sites related to historical periods, e.g., 19th-20th centuries reflections on the transformations of 1938-1945;

- related to cultural structures, like the European socio-economic modernisation processes the culture of weavers/textile industry.

The historical stratum, serving as the source for the creation as well as supression, 'forgetting', and instrumental use of the sites of memory of the Owl Mountains area can be presented, in much simplified terms, as follows:

- In the middle ages, the Owl Mountains were a border between emerging statehoods, separating the states of the Přemyslids (the Kłodzko Land) and the Piasts (Silesia).

- Nomenclature: Czech Mountains, Owl Mountains since 17th century (possibly from the similarity of names with gold diggers); 
- Colonisation of the area by the Silesian Piasts in 13th century (involving mainly German settlers);

- The first document mentioning a settlement is dated on 1288;

- national sites of memory, such as the cultural heritage of the nations of displaced population, transfer of national sites of memory along with the settlers from other regions of Poland/Europe, adaptation of nation-wide sites of memory;

- The first documented form of the place name comes (Bela) comes from 1288 and suggests it was originally named "Biała" (White). It is also confirmed by an entry from 1379 ("zur Bele"). From the 15th century on, a form adapted to German pronuciation, "Belau" or "Bielau" is observed (Berlaw 1472 , Bylaw 1511). Finally in the 16th century the prefix lang (German for "long"), referring to the unusual geographical extent of the villate $(8 \mathrm{~km})$, became permanent: Langenbilav (1665), Langenbielau (1758). A dialectal form Biele was used locally at the same time.In 1945, Polish authorities repolonised the name to Bielawa, even though most likely this form has no historical grounds;

- Since 1392 Bielawa and the whole Duchy of Świdnica belonged to the Czech Kingdom;

- In 1526 Bielawa and the entire Silesia came under the Austrian Habsburg rule;

- In 1530, when the Reformation was spreading, the people of Bielawa converted to Lutheranism;

- The 17 th century saw wide development of weaving in Bielawa. In 1718, the first manufacture was founded;

- In 1742 Bielawa, whole Lower and greater part of Upper Silesia came under the rule of the Kingdom of Prussia; settlement of weavers in the Owl Mountains continued;

- In 1805 , a local entrepreneur established a weaving mill. Years later, his factory developed significantly, becoming the largest textile manufacturing plant in Silesia (under the name Christian Dierig AG);

- 5 June 1844, an uprising of weavers erupted, who demanded higer pay for their work. These bloody events were described by future Nobel prize winner Gerhart Hauptman in his play Weavers;

- Development of textile industry;

- The second half of the 19th century saw rapid development and modernisation of Bielawa.

- Bielawa was granted town status in 1924; 
- During World War II, Germans opened a subcamp of the Gross-Rosen concentration camp near Bielawa.

- In April 1946, the action began to resettle the residents of Bielawa to West Germany;

- The arrival, after 1945, of immigrants from beyond the Bug River (e.g., from Kolomyia), settlers from various parts of Poland, and a group of Jews;

- Placement of Greeks in the towns of the Wrocław Voivodeship: Jelenia Góra, Wałbrzych, Bielawa, Dzierżoniów, Legnica, Niemcza (1949-1952).

\section{NATIONAL SITES OF MEMORY}

\section{THE CULTURAL HERITAGE OF THE NATIONS OF DISPLACED POPULATION, TRANS- FER OF NATIONAL SITES OF MEMORY ALONG WITH THE SETTLERS FROM OTHER REGIONS OF POLAND/EUROPE, ADAPTATION OF NATION-WIDE SITES OF MEMORY.}

The 1954 performance of the play Weavers by the German 1912 Nobel Prize winner Gerhart Hauptmann by the Workers' Theatre in Bielawa is one of the earliest cases of reaching for components of the past before 1945. There may have been several reasons for reaching to this layer of cultural heritage. The author of the play, first performed at an imperial theatre in 1892, was a playwright well-known in Europe; the message of the play itself coincided with the promoted ideology; and it was based on the memory of a real riot of weavers from Bielawa and Pieszyce in the early June 1844. The dramatic events caused by the poverty of weavers from the Owl Mountains led to the destruction of factories, military intervention, and over a dozen deaths. The uprising of the weavers of Pieszyce and Bielawa reverberated widely across Europe; Karl Marx reflected on it, Heinrich Heine and other authors referred to it in their works. Hauptmann was not the only one inspired by these events, yet his play invoked more general ideas of dignified life and solidarity. It was not just the event which reverberated across Europe: the Nobel Prize for the playwright who wrote a play based on it also brought him European-wide recognition. Performed by the Workers' Theatre, it was addressed to the community of Bielawa which took over the old Dierig family textile mill. The pla was performed in the scenery of the mill. The message it carried fit in the category of world history and the politically favourable perspective of class struggle. The Weavers were recalled into collective memory as a literary depiction of the workers' movement history and not part of the regional heritage, even though Hauptmann came from Silesia, where he died in 1946 in his villa in Jagniątków near Jelenia Góra. Together with his works, he was perceived as an illustrious European 
playwright but not as a representative of German culture or his "small homeland". This approach to historical events and their literary interpretation held in the following decades as well. In spite of social, political, and cultural changes, typical to the turn of the 1990s, both the events and their artistic interpretation have kept their place in the collective memory of the inhabitants of Bielawa and regional history.

The Weavers play and its author, G. Hauptmann, are referenced in the works of the modern local poet Adam Lizakowski. Whereas the chronicler of Bielawa Krzysztof Pludro characterises the place of the weavers' riot in the local social cosciousness as follows: "Even today, after 160 years, the drama of the events in June 1844 is still an inspiration for artists. Over these years the state borders have changed, so have the entire populations of Pieszyce, Dzierżoniów, Bielawa, and the whole Owl Mountains, yet the legend of the freedom spurt of simple people, weavers, who made a stand for what they believed the most precious, their human dignity, is still alive. (...) Thanks to a Polish poet, the history of the weavers of Pieszyce and Bielawa is made a part of our common, German and Polish history. The past interweaves with the present, such as the warp and weft threads do, forming a cloth."

As the Owl Mountains region historian Rafał Brzeziński writes, "[t]oday, the tragic events of the 1844 weavers' riot are recalled by the bilingual memorial plaque set on 4 June 2004 by the town hall in Bielawa: In this place in 1844, the final act of the uprising of Silesian weavers took place. We commemorate this fact for posteriority on its 160th anniversary." In 2004 a common Polish-German celebration of the 106th anniversary of the Silesian weavers' uprising was held, and since 2013 the Raid on the Route of the Owl Mountains Weavers' from Pieszyce to Bielawa has taken place. 6 June 2014 , on the 170th anniversary of the events, a memorial plaque was unveiled on the old building of the "Prussian Manor" hotel where Hauptmann lived and wrote his play. At the turn of the 21 st century, the issues were also present in local publications.

The 1955 performance by the Workers' Theatre of the unstaged 1860 play Popiel and Piast by Mieczysław Romanowski, which according to Pludro refers to "legends and stories created at the cradle of our history", has yet another meaning. "The play went to the roots of national traditions, which were recalled in Silesia as the right historical heritage. Also, the invoked heritage was national, Polish, and not regional. In this role, it was meant to be one of the sources to shape the common cultural denominator in the otherwise culturally diverse area.

${ }^{2}$ K. Pludro, Kronika Bielawy. Od czasów najdawniejszych do $1945 \mathrm{r}$. [Chronicle of Bielawa: From the earliest times to 1945], Dzierżoniów 2007, p. 118.

${ }^{3}$ R. Brzeziński, Życie w dawnej Bielawie: Ludzie, miejsca, wydarzenia [Life in old Bielawa: People, places, events], Wrocław 2008, p. 235.

${ }^{4}$ K. Pludro, Kronika Bielawy. Część V..., p. 117. 


\section{REGIONAL SITES OF MEMORY}

\section{SITES OF MEMORY OF THE OWL MOUNTAINS AREA}

A national justification was also sought when the elements of the past were recalled as evidence of regional identity. In Przesieka [Glade], a short-lived supplement to the local textile journal Krosno [Loom] from 1958, with ambitions to spark inerest in the history of the Dzierżoniów region, there were attempts by one of the settlement groups at seeking a local identity. A letter from a reader told "about Poles from the Romanian Bucovina, who settled in the Dzierżoniów County after the war. The ancestors of these settlers supposedly came from Sobótka in Lower Silesia, from where they migrated to Bucovina after Prussia took control of Silesia in the 18th century. Currently then, according to the author of the letter, they return to the land of their ancestors, in a way."

A problem arose, however, of the necessity to refer to the regional memory of the former dwellers of Bielawa and its vicinity, originally doomed to oblivion. In the town of Warendorf in Westphalia, displaced Germans from Bielawa started their own magazine, Hohe Eule. This topic was taken up in Krosno from 1960 from the perspective which both stressed the permanence of post-war frontiers in their consciousness and showed understanding of their feeling towards old homeland. Yet it was the perspective of the current inhabitants' future, permanence of settlement, and taken over property which determined the interpretation of the "small homeland" memory in their predecessors from before 1946.

It is characteristic how the chronicler of Bielawa evaluates this phenomenon. While he noted that "when the German inhabitants left Bielawa, the cultural and civilisational continuity of the town, formed by the centuries of habitation, was broken. It threatened with a cifilisational and cultural void, which had to be avoided at all cost. This task was successfully addressed by the people (...) who, fulfilling their passions, created from scratch the Polish cultural subsoil in Bielawa and its vicinity, built a bridge 'between the old and new years', i.e., filled the vacuum which formed after these lands were abandoned by the German population." In spite of using the catchy metaphor, the chronicler does not see any place for the German cultural heritage in the process he describes. In his approach, the sources of local history are the

${ }^{5}$ K. Pludro, Kronika Bielawy. Od czasów najdawniejszych do $1945 \mathrm{r}$. [Chronicle of Bielawa: From the earliest times to 1945], Dzierżoniów 2007, p. 131.

${ }^{6}$ K. Pludro, Kronika Bielawy. Od czasów najdawniejszych do $1945 \mathrm{r}$. [Chronicle of Bielawa: From the earliest times to 1945], Dzierżoniów 2007, p. 137-138. 
activities of the Polish pioneers, from 1946 on, which were to ensure the "cultural and civilisational" continuity in the land abandoned by their predecessors. Yet, without referencing the existing material cultureand reflecting upon the adaptation of cultural achievements of its previous hosts. The inevitable taking over of the achievements of the weaving industry in Bielawa from its German owners and managers, which did not permit ignoring the past enitrely, is also interpreted in this view. Later as well, after the political breakthrough of the 1990s, the constructed sites of memory would mainly refer, in the Owl Mountains region, to the activities of the pioneers who toiled to build a uniform local community out of a variety of settler groups. At the turn of the 21 st century, it is still the frequent form of practising regional history and education on these topics. It is also worth to notice that there are no distinct attitudes towards the Czech borderline.

This is how the chronicler of Bielawa described the role of the textile circles' magazine Krosno, published 1947-2001, regarding the past: "Throughout its whole history, Krosno was part of the process of embedding the poeple of Bielawa and growing into the new, post-war reality, in the integration process of the inhabitants hailing from all sides and corners of the pre-war Poland. (...) The magazine has played a special role since the breakthrough of October 1956. It was then it became the magazine of the whole Dzierżoniów Land, the whole Owl Mountains region, telling about the history and monuments of towns and villages, about the authors of retional culture, and people shaping the current face of the county."

Since the 1970s, and particularly after 1990, groups of former inhabitants, as well as people connected to Bielawa in other ways, have started coming to the town. Pludro called these peregrinations "sentimental voyages of the old Bielawers". They maid it necessary for the inhabitants of Bielawa to recall the memory of its old dwellers. The chronicler stresses the opinions of the German guests on the changes which occurred in the textile industry and the partnership agreement with the town of Lingen in Lower Saxony, where many former inhabitants of Bielawa settled after the war. The "Declaration of Partnership" expressed the belief that "partnership and friendship can facilitate overcoming the prejudices from the past as well as the obstacles and divisions into the Western and Eastern parts of Europe." While the so-outlined search for common areas of inter-cultural communication referred to the past only to a lesser extent, it established the conditions necessary for more frequent contacts than before and limiting mutual stereotypes. The cultural exchange which resulted

${ }^{7}$ K. Pludro, Kronika Bielawy. Lata 1990-2004 [Chronicle of Bielawa: 1990-2004], Dzierżoniów 2005, p. 131. 
from this agreement, however, primarily involved the current cultural experiences and not the memory of the past.

The search for the sites related to it was, nonetheless, the pastime of groups of Germans who more and more often visited Bielawa with after 1990. Thus, the issue of its history before 1945 appeared in the context of their visits. Their presence and search for the traces of the presence of their own and their ancestors made it impossible to marginalise the pre-war history any more. It took the form of activatting the sites tied to the old German culture in the memories of the current inhabitants of Bielawa and impacted the literature related to the town. The prose of Hubert Dobrzaniecki may serve as an example here. In time, at the turn of the 21 st century, there also came works devoted to Bielawa and the Owl Mountains region, e.g., by Rafał Brzeziński, translated into German. Such editions, important for the German visitors, were significant in the inter-cultural communication based on the memory of the past. The groups coming from Israel showed a different motivation. They were, as Pludro states, "former Gross-Rosen prisoners, who came with their families to see the martyrdom sites."

Some historical memory turned up in the practice of local authorities. The chronicler noted that "on 23 May 1995 a particular session of the Town Council took place (...) exactly on the 71th anniversary of the first CC session in Bielawa (23 May 1924)" (after it obtained its town status - JJ). ${ }^{9}$ The present coat of arms of the town is also a remnant of the German past. Bielawa received its town status in 1924. Its arms bear the colours of blue and white (per fess azure and argent; in chief a stylised weavers shuttle fesswise argent, in base a shuttle fesswise azure), topped with a crown of medieval walls. The latter component was added even though Bielawa, as a village, had no encircling walls..$^{10}$ The continued tradition of local government was the basis for shaping the local memory here. Direct contacts between the former and present inhabitants of Bielawa, inevitable since the 1990s, facilitated the creation of a forum of social communication, also in the field of organising the forms of local community life. The local government history before 1946 did not cause any conflicts in the interpretation of the town's past. The symbolism reminiscent of weaving and textiles joined ages and communities, since the Polish settlers took over and continued the local textile industry. It corresponded with the direction of civilisational development of the town into the early 21 st century, regardless of the changing political, systemic, and social configurations.

\footnotetext{
${ }^{8}$ K. Pludro, Kronika Bielawy. Lata 1990-2004 [Chronicle of Bielawa: 1990-2004], Dzierżoniów 2005, p. 59-63. ${ }^{9}$ K. Pludro, Kronika Bielawy. Lata 1990-2004 [Chronicle of Bielawa: 1990-2004], Dzierżoniów 2005, p. 78.

${ }^{10}$ K. Pludro, Kronika Bielawy. Od czasów najdawniejszych ..., p. 206.
} 
The memory of the German history was also invoked due to the claims of "persons of German nationality who demanded to be given back the real estate which belonged to them or their families before the war." on what grounds Poland took over the western and northern territories, stressing this irreversible fact and its legal consequences. ${ }^{12}$ Nevertheless, they led to some concerns which did not facilitate the functioning of the "sites of memory" related to the prewar dwellers of Bielawa in the consciousness of its inhabitants. They disturbed the sense of permanence of the taken-over property and post-war borders. Indirectly, they also caused an aversion to the past before 1946, becoming a significant barrier to the activation its components in the local consciousness.

The sites of memory in Bielawa also took the form of remnants of material culture. Penitential crosses, referring to the great hunger of 1804-1805 were erected in Upper Bielawa along the present-day Waryński St and on the wall surrounding the Church of the Assumption. They commemorate a crime committed when fighting for food. In the Dzierżoniów County as well as in the whole Lower Silesia, erecting crosses as a penalty and penance for committed crimes was a common practice, traceable back to the 15th and present in the following centuries. The immigrant Polish population interpreted them initially in a different way, however, as the traces of the Christianisation of Silesia. ${ }^{13}$ These beliefs did not relate these sites to the German culture but rather to a more universal cultural form, i.e., Christianity introduced to Silesia under the influence of the states of Great Moravia, Czechs, and the Piasts.

The remnants well embedded in the cultural landscape of the Owl Mountains were the observation towers on the peaks of Wielka Sowa and Kalenica. The Chronicle of Bielawa says that "the tower on Wielka Sowa was opened for the tourists with ceremony on 24 May 1906. It was named Bismarck's Tower (Bismarckturm) (...) Tourist trails crossing Wielka Sowa are the Main Sudety Trail (Pol. Główny Szlak Sudecki) marked in red, the trail to Srebrna Góra marked in blue, to Rościszów and Walim in yellow, to Pieszyce in black, and to Ludwikowice Kłodzkie in green. After World War II, the tower on Wielka Sowa was named after General Sikorski." ${ }^{\prime 4}$ Soon, the tower became a symbol of the Owl Mountains, even though it was neglected for several post-war decades, and its patrons changed: however, neither General Władysław Sikorski nor the outstanding ethnographer Mieczysław Orłowski became embedded in the local collecive memory in this role. For political reasons, its original

\footnotetext{
K. Pludro, Kronika Bielawy. 1990-2004, p. 82.

${ }^{12}$ K. Pludro, Kronika Bielawy. 1990-2004, p. 82.

${ }^{13}$ K. Pludro, Kronika Bielawy. Od czasów najdawniejszych ..., p. 95.

${ }^{14}$ K. Pludro, Kronika Bielawy. Od czasów najdawniejszych..., p. 163-164.
} 
patron was doomed to oblivion. A cautious approach to the remnants of German material culture could be seen on the pages of Krosno in the critical evaluations of the devastation of the existing technological infrastructure. "In its time (emphasis mine - JJ), this hill (now Park Hill, pol. Góra Parkowa in Bielawa - JJ) held a small chalet-restaurant, there were benches standing along the wood paths, and the copper topographic plaque on the tower explained the vicinity of Bielawa to visitors. Today, all these attractions are but a memory." It is characteristic that the authors of the park arrangement were not named by the author of the note, in spite of his visible approval of the now past results of their work. There were traces of the past in local memory in the later decades as well, yet they never stressed the nationality of their creators. The chronicler of Bielawa quotes the words of the town's mayor about one of the observation towers, spoken in 1990: The magnificent observation tower on Kalenica is dying due to the lack of conservation. It is dying in front of its owners, as Kalenica lies within the administrative borders of Bielawa. It is thus entitled to call for help, beg for memory. The appeal of the town's steward does not mention the builders of the observation tower and its sightseeing function before 1945. Even the chronicler, relating the subsequent restoration as well as the acts of vandalism, does not account for this historical perspective, e.g., by referring to the earlier concepts of restoring this now historical building. The role of Kalenica is perceived solely from the viewpoint of its sightseeing value, in its present-day understanding, facilitating the development of local tourism. The chronicler stresses that the "peculiar landscape of the Owl Mountains was unique in the county. The tourist trails crossing the mountain range lead through charming parts of the Park (Owl Mountains Landscape Park - JJ), culminating in two observation towers on Wielka Sowa and Kalenica, with some of the most beautiful panoramas in all Sudety." Still, the genesis, building conditions, or creators of the two towers were not mentioned. ${ }^{16}$ While their history was known, it did not become a regional 'site of memory', even though the processes shaping the cultural landscape were not an issue leading to conflicts in the past. No potential for the development of cultural tourism in the area was found in recalling these elements of the past.

An important date for the shaping of the local symbolism of Bielawa, attesting to its regional and German heritage, was 1 September 1939, when the monument of the Owl was unveiled there. As the Polish chronicler described it, "The plinth of the Owl remains the memento of that fateful day. The unveiling of the Owl monument, the symbol of the Owl Mountains, was intended as the final point in the celebration of the 650th anniversary of Bielawa in the previous year, 1938. The ceremony was

${ }^{15}$ Krosno 1958, No. 14/15, quoted in K. Pludro, Kronika Bielawy. Część V..., p. 133.

${ }^{16}$ K. Pludro, Kronika Bielawy. Lata 1990-2004..., p. 43-44. 
modest, without much festivities, due to the martial law on 1 September 1939." 7 The German authors of the Owl monument intended to refer to the history of the Owl Mountains region, a "small homeland", to its economic, cultural, and social development. Unburdened by political connotations, it remained a symbol of Bielawa even after 1945, albeit in a strictly regional sense. The Owl monument was related to the formed by the previous inhabitants yet culturally domesticated landscape of the Owl Mountains. Such an approach to the past did not identify the symbols found by the Polish settlers directly with the German culture but with regional culture instead, where the issue of nationality was not so clearly stressed. Designed by the German stewards of Bielawa in a specific historical situation, the monument never managed to adopt the intended symbolic roles. It served the latter, as a symbol of the town and region, in an entirely different reality. Without referring to the centuries of history of Bielawa before 1946, it connected the settlers who came later from various territories.

The 1990s also brought the interest in the pioneering past of Bielawa and its vicinity among some of the Polish diaspora from this region in the US and Canada. The Bielawa and Lower Silesia Association "Great Owl" (Pol. Wielka Sowa) was founded. ${ }^{18}$ However, this external initiative cultivated the memory of the first Polish settlers, strengthening the national trends in creating local sites of memory and the regional historiographic mainstream.

The turn of the century brought changes. That time saw a number of popular local publications related to the past: Chronicle of Bielawa, Legends of the Owl Mountains, Uprising of the Owl Mountains' Weavers, financed by the town authorities..$^{19}$

In particular the first of these publications tapped the sources of the past of Bielawa, and the inhabitants of the town began seeing the author of the Chronicles, Krzysztof Pludro, as its chronicler. Rafał Brzeziński published the book Life in old Bielawa: People, places, events in Polish and German. Based on the works of the German chroniclers of Bielawa, the Catholic teacher Anton Hanning from 1886 and the Lutheran teacher Fritz Hoenow from 1931, it is not a monograph of the town yet evokes elements of the 'unwanted heritage'. In 2009, Rafał Brzeziński launched an interesting project "Bibliotheca Bielaviana" as part of the Municipal Public Library, which was realised in 2009-2013. The majority of historical papers included in it involved the 'pioneering' period of settlement in the region (sport, parishes and religious groups, education, workplaces, architecture of local residences, and social problems of the 1980s and 1990s), rarely touching the issues from before 1945. Nonetheless,

\footnotetext{
${ }^{17}$ K. Pludro, Kronika Bielawy. Od czasów najdawniejszych..., p. 256.

${ }^{18}$ K. Pludro, Kronika Bielawy. Lata 1990-2004..., p. 80.

${ }^{19}$ K. Pludro, Kronika Bielawy. Lata 1990-2004..., p. 127.
} 
this promising project yet has to develop, therefore it would be premature to assess its creation of certain sites of memory. It might be worth to mention that the author of "Bibliotheca Bielaviana" is a historian of the young generation, who knows the history of Bielawa well and has published important works on this topic. The Library has also gathered an archival collection related to the post-war history of the textile industry. The Museum Outlet, operating since 2009 at the Library and later transformed into the Regional Research Department, devoted more room to the former dwellers of Bielawa. Its sections, such as tourism, industry, chemist's, publications, art, sport, religion, atelier, trade and commerce, home and man, contain also elements of German material culture. Only the military section is entirely devoted to the activities of the combatants of Bielawa. The Museum Outlet specialises in presenting the everyday life of Bielawa without limiting itself on purpose to its Polish character and, like "Bibliotheca", is a new project. The nature of the collection is, to some extent, the product of the donated private collections, largely connected to Bielbaw, the no longer existing cotton industry plant. The appeal for donations of relics was published in Polish and German. The Museum Outpost also participated in the 2012 European Herigat Days by invoking on postcards the images of old chalets in the Owl Mountains, mostly demolished or destroyed after 1945, and offering lectures on old regional holidays in Bielawa. ${ }^{20}$

Currently, both the German and Polish past is documented by websites like Bielawa then and now (Pol. Bielawa dawniej i dziś) and others. ${ }^{21}$ A number of websites show the natural, tourism, and historical assets of the region. This information is part of the offer addressed to German tourists, just like the bilingual publications by Rafal Brzeziński. Guidebooks to the Owl Mountains, like that written by Tomasz Śnieżek, play a similar role. ${ }^{22}$

Educational projects, however, often only address Polish achievements. In the project "Cultural heritage of the Owl Mountains", youth from three Owl Mountains counties, Walim, Głuszyca, and Jugów, documented the memories of their grandparents, who organised the social life in the taken over areas. ${ }^{23}$ Conversely, since 2007 the Owl Mountains communes have realised EU projects in broadly understood cultural tourism, e.g., "Owl Mountains - heritage of the multicultural history of Lower Sile-

\footnotetext{
${ }^{20} \mathrm{http}: / /$ bibliothecabielaviana.com/.; http://mbp.bielawa.pl.

${ }^{21} \mathrm{http}: / /$ mediagroup.republika.pl/bielawa/bielawa.html; http://www.bielawa.net.pl.

${ }^{22}$ R. Brzeziński, Życie w dawnej Bielawie. Das Leben im fruheren Langenbielau. Ludzie, miejsca, wydarzenia, Wrocław 2008; T. Śnieżek, Góry Sowie. Przewodnik [Owl Mountains: Guidebook], 2012;W cieniu Wielkiej Sowy [In the shadow of Great Owl], coll. work, Dzierżoniów 2006.

${ }^{23} \mathrm{http}: / /$ www.gimgluszyca.cba.pl/index.php?option=com_content\&view=article\&id=322:dziedzictwokulturowe-gor-sowich\&catid=34:newsy.
} 
sia - a promotional and informational campaign." 24 'Multiculturality' usually involved depicting various aspects of the social life typical of the Owl Mountains region over the years. The presented history did not begin with the post-war Polish settlement but went back to the origins. However, the promotion mostly involved sites of tourism value (the observation towers on Wielka Sowa and Kalenica), churches, the 'Hunting lodge' in Jodłownik, without using them to invoke the 'forgotten heritage'. Indeed, the constructed view of the past was meant to radically change the image of Bielawa in social consciousness, which had so far been associated with weaving and cotton industry, to stress its tourism and ecological nature. Such a constructed narrative is not conducive of cultivating the forgotten industrial heritage. Whereas the current owners of the Dierig mansion, which site now serves as a hotel, accept the history for the reasons of prestige. ${ }^{25}$ What is being stressed most, however, is their residential past, not directly tied to any deeper reflection on the creators or owners of the buildings.

In the analysis of current tourism and cultural potential of the Dzierzioniów County, many items from the region of Bielawa related to its history before 1945 remained unnoticed. The author of the report, Armin Mikos v. Rohrscheidt, named the following important sites cultural heritage: in the first place, the neo-Gothic church in Bielawa, the von Gelhorn Palace in Pieszyce, sites of demonstrations during the Riots of Silesian Weavers in 1844, the Dierig villa in Bielawa now serving as a hotel, the seat of the Municipal Office of Educational Institutions in Bielawa in the style of Dutch Mannerism, and "numerous buildints associated with the centuries-long presence of Germans" in general. Among the places related to the plot of literary works of international and national significance, the author of the analysis named Pieszyce and Bielawa again, the sites of demonstrations of the Owl Mountains weavers and the site of the play Weavers by G. Hauptman, and Bielawa as the place of origin of Reynevan, the protagonist of the Hussite Trilogy by A. Sapkowski. The Museum Outlet in Bielawa, now the Regional-Research Department of the Municipal Public Library in Bielawa was listed among working museums, and among cultural routes, the Pieszyce-Bielawa Route following the Route of the Silesian Weavers' Uprising, only a few kilometers long. Analysing the cultural potential, the author eventually showed that, from the perspective of literary tourism, the major assets were amassed in Pieszyce and Bielawa. Still, Rohrscheidt considered the lack of separate thematic expositions and marking of the local tourist trails as serious drawbacks, even if he did not suggest that they might be related to German or Czech cultural heritage, and the inability to visit a number

${ }^{24} \mathrm{http}: / /$ gorysowie.org/.

${ }^{25} \mathrm{http}: / /$ www.hoteldebowy.pl. 
of historical residences due to their status as private property. "The potential brand products," Rohrscheidt writes, "may be:

1. a literary and film tourism offer, focused on the Pieszyce and Bielawa region, introducing industrial, historical, and social themes, based on the plot of the Weavers' Riots and the works describing the event, such as G. Hauptmann's play;

2. using the literary plot of Sapkowski's popular Hussite Trilogy for the organisation of a cultural and tourism event in Bielawa, with associated packages. (...)

This kind of offer might attract tourists with various profiles of interest. Pieszyce and Bielawa are where the plot of the play Die Weber (En. Weavers) takes place. It depicts the events related to the riot of the 19th-century Silesian homeworkers, exploited to the brink of starvation. The Nobel Prize in Literature was awarded to its author with a clear indication of the significance of his work, thus improving his rank and making him known worldwide. The actual historical sites (...) and the topicality of work-related exploitation may become the basis for developing a local tourist product. (...) Also the fact that Bielawa is the "place of origin" of the fictitious protagonist of the so-called Hussite Trilogy by Andrzej Sapkowski, which is very popular among the youth, may be the basis for constructing yet another local thematic product." ${ }^{\text {26 }}$ Thus, in the invoked report, it is mainly the Weavers' Riot and its literary depiction which have been fixed in the heritage of the pre-1945 memory.

\section{EUROPEAN SOCIO-ECONOMIC MODERNISATION PROCESSES}

\section{THE CULTURE OF WEAVERS/TEXTILE INDUSTRY}

The post-war history of Bielawa, until the beginning of the 21 st century, were tied to the textile industry, created by the Dierig family since 1805 on the basis of weaving, which went back to the middle ages. The fates of the village of several thousand people, then town since 1924, were connected to the development of this branch of industry, regardless of social, economic, and political changes. The symbols of its creators, however, were being carefully erased, even though the traditions of weaving and textile industry, present for centuries in this area, were continued. The pre-war Dierig St (now Piast St, Pol. Piastowska) has never returned to its name, even though

${ }^{26}$ A. Mikos v. Rohrscheidt, "Raport: Analiza potencjału turystyczno-kulturowego powiatu dzierżoniowskiego" [Report: Analysis of the tourism and cultural potential of the Dzierżoniów County],Turystyka Kulturowa, 2013, 2, p. 69-85. 
the Dierig family was clearly essential to the modernisation of the region, did much for the local community, and their concern had branches in Germany too.

Even the name of the company bore no trace of the past. The former Christian Dierig Aktiengesellschaft established in Bielawa was renamed after the war as the State Cotton Products Factory No. 1 in Bielawa (Pol. Państwowa Fabryka Wyrobów Bawetnianych $\mathrm{Nr} 1 w$ Bielawie), or "Bielawa One" (Pol. Bielawska Jedynka). The next name, from 1950 on, was 2nd Polish Army Cotton Industry Plants in Bielawa (Pol. Bielawskie Zaktady Przemystu Bawetnianego im. II Armii Wojska Polskiego). It referred to the army formation operating in 1945 in Lower Silesia and was purely political. The subsequent name, Cotton Industry Plants "Bielbaw" S.A. (Pol. Zakłady Przemystu Bawetnianego "Bielbaw"), in use since 1992, was not, and the economic and political conditions were different. Being ideologically and historically neutral, it only referred the type and place of production.

It may be due to the German character of the pre-war factory and the post-war historical policy of supressing the German heritage from collective memory that the Christian Dierig brand, already known in Europe, was not used in the names of the company. Historical policy bested marketing, even though the People's Poland times knew examples of the other approach. The nationalised Wedel's confectioneries were renamed the 22 July Confectionery Plants (former E. Wedel) (Pol. Zakłady Przemystu Cukierniczego "22 Lipca" (dawniej E. Wedel)), combining the political correctness with the product name popular in Poland and abroad. The only trace of the past are the names of the Weavers' St (Pol. Tkacka), a side street in Bielawa, and the Textile Workers' (Pol. Wtókniarzy) Housing Cooperative. The industrial buildings, unique in Europe, are now also gradually being demolished. This means an eradication from collective memory of virtually all traces of the cotton industry in Bielawa, absent since 2008 , and its pre-war history in particular.

The Bielawa Chronicle only notes that "in the 1970s, the company magazine Krosno published a cycle of documents entitled "Troubles and hopes of Mr Gottfried". It contained selected passages from the letters of Gottfried Dierig from 1944, the copies of which were preserved in the archive of the 2nd Army CIPB., ${ }^{27}$ Now, "the beautifully restored old villa of Dr Wolfgang Dierig (built in 1901) houses the hotel and restaurant Hotel Dębowy (4 Janusz Korczak St)." ${ }^{28}$ The mentioned letters came from the latter period when the factory in Bielawa was managed by the Dierigs, therefore they could be an important source for the editors of Krosno about the moods

\footnotetext{
${ }^{27}$ K. Pludro, Kronika Bielawy. Od czasów najdawniejszych ..., p. 283.

${ }^{28}$ R. Brzeziński, Życie w dawnej Bielawie..., p. 118.
} 
among the owners before its inevitable transfer into the Polish hands. Still, they did not intend to refer to the pre-war history of the textile industry in Bielawa.

The second socially important part of the modernisation of the Owl Mountains mini-region was the construction of the Owl Mountains Railway. Put to service gradually in the early years of the 20th century, it linked Dzierżoniów, Pieszyce, Bielawa, Srebrna Góra, Ścinawka Średnia, and Radków. It greatly contributed to the development of economy and tourism in the region. It was buit to facilitate the communication between textile industry centres on one side of the Owl Mountains with the collieries in the Nowa Ruda area. Since it was a mountain route, design solutions unique in Europe were used, which well illustrate the European high technological culture at the turn of the 20th century. The route of the Railway also made it a remarkable tourist attraction. However, economic crises and political conflicts in the latter century prevented its development. Inadequately maintained in the intra-war period and declining in the post-war years, it was finally shut down in the late 1970 s. $^{29}$ The remnants of railway infrastructure can still be found along its former course. This railway was a regional symbol for the people of Dzierżoniów, Bielawa, and Pieszyce even after the war. It remained in the social memory of the inhabitants of the Owl Mountains area, in the local literature, and as the decrepit railway stations.

Indubitably, the remnants of the unique industrial architecture and railway construction are the heritage of German technical thought. However, they did not function in the local social consciousness as such. They were connected with the regional cultural landscape instead, "domesticated" by the Polish inhabitants of Bielawa, without treating the relics of industrial and railway constructions as a cultural heritage worthy of preservation. This is indicative of the passive attitude of the local communities in the Owl Mountains towards the dilapidation of these objects. During the transformations in the area in the second half of the 20th century, it was no longer economically sound to maintain the remnants of German technology. No conservators were interested in them either. This attitude has a supra-regional aspect as well: pieces of old technology are not always associated with historicity and appropriately protected.

\section{SUPPRESSION OF MEMORY}

The monuments of the German past in the forms of material culture forms were mostly doomed to oblivion. The monuments to soldiers-victims of the French-

${ }^{29}$ A. Szynkiewicz, Eulengebirgsbahn - czyli nierealne marzenie jakie zrealizowano http://www.kolej.one.pl/ halski/ linie/sowiogorska/eulen2.html (accessed: 25.03.2015). 
Prussian war have been lost. (K. Pludro, Kronika Bielawy. Od czasów najdawniejszych..., p. 137.) It is also the case of the remains of the family tomg of the Counts Sandreczki, who owned the Bielawa estate since 1672 . Now, they are but piles of rubble with remnants of constructions sticking out, which do not allow one to tell their nature, and the memory of the family is absent from collective consciousness. In the majority of cases, the monuments to fallen soldiers, members of cultural, sport, or tourist associations, or just inhabitants for their merit to the local community either were lost or became marginalised. There is an extant monument to fallen soldiers at the cemetery by the Assumption Church, yet it does not sefine the 19th-century conflict in which they gave their lives.

The local gymnastic society of the time erected monuments to the fallen in World War I. After World War II, a monument from 1920 was buried in the embankment of sports grounds. A monument to the fallen employees was also erected by the owners of the Christian Dierig GmbH in 1924; a year later, a great, 8 meters high monument to all the World War I victims from Bielawa was unveiled on the initiative of the local authorities. Both were doomed to oblivion. Brzeziński writes about their fates that, "when Polish population began coming to Lower Silesia after World War II, they destroyed everything that was German. What was left of the demolished Dierig monument was buried under the stands of the old stadium. The municipal monument was dismantled and used as construction material for the private house of the town head of the time."30 The same researcher, describing the construction of the Lutheran church in Upper Bielawa noted that "from the beginning of the construction in the 1930, the tower was topped by a cross, which was then swapped for a rooster symbolising wisdom. After World War II, Polish settlers, unaware of the symbolism, destroyed the image of the rooster above the altar, believing it to be an ungodly example. Also, in the 1970s, the people of Bielawa destroyed and ploughed over the 19th-century Lutheran cemetery, only a few years after the last burial among the few remaining Lutherans took place."31 It was not just symbolism referring to military and political conflicts of the 19th and 20th centuries until 1945 which was being suppressed from memory but some parts of social life as well. It also included spheres beyond the particular interest of politics and historical policy. Rather than that, they impeded the cultural "domestication" of the taken over territories, and the suppression phenomenon was local.

The monument to the teacher and ethnogrpher Karl Jäschke, erected in 1900 on the slopes of the Park Mountain (present-day name) has not survived, nor has the

\footnotetext{
${ }^{30}$ R. Brzeziński, Życie w dawnej Bielawie..., p. 77-79.

${ }^{31}$ R. Brzeziński, Życie w dawnej Bielawie..., p. 77-79. p. 40-41.
} 
restaurant built in the early 20th century on its top, burned in May 1947 by a drunken mob celebrating the Victory Day. The only remnant of the old facilities is the sightseeing tower, called Observer, built in 1925. The monument to Paul Felsman, the chairman of the Bielawa Chapter of the Owl Mountains Society, erected on one of the hills encircling Bielawa, has survived as one of the few. Whereas the 1930s swimming pool with gastronomic facilities has not, in spite of the attempts at reclaiming this recreational area after World War II by constructing a wooden summer theatrical scene.

The suppression of memory also involves cultural institutions. Referring to the history of cinemas in Bielawa, Pludro wrote that the first one operated as "an outlet of 'Schauburg' and even bore the same name. The first film show in Bielawa took place on 22 August 1927. After World War II, the cinema was named 'Slav' (Pol. Stowianin). Soon, Bielawa received another cinema. It was the so-called 'Palast Kino', located in Central Bielawa in the School St. Thoroughly rebuilt and modernised, it was renamed 'Palast Theater'. The first film was played there on 10 November 1927. After World War II it was known as the 'People's Cinema. The former does not exist any more, and the building of the latter now hosts the "Czako" club. ${ }^{32}$

At present, some monuments of the technical cultural heritage are also disappearing. In the course of the systemic and economic changes of the recent quarterof the century, the former Dierig plant (then BZPB im. II Armii WP, BZPB Bielbaw) were finally purchased by Marian Kwiecień in 2001. The plant soon ceased its production, and the industrial buildings, the only such complex in Europe, are being demolished. ${ }^{33}$ No conservatorial actions were undertaken to prevent this process, the Dierig industrial facilities were not considered an important component of the cultural landscape or heritage worthy of preservation. The system of factory buildings, constructed on a large scale in the 19th century, is slowly but inevitably disappearing from the local urban space.

The analysis of older and current plans of Bielawa does not show references to pre-war traditions either. The street patrons are characters from the recent or more remote history of Poland, politicians, soldiers, people of culture. There are names devoted to historical events, from the times of People's Poland too. They are indicative of the local historical policy. Only a few are translations of old German names (Strażacka, Bankowa, Akacjowa, Kolejowa, Polna, Parkowa, Nowobielawska, Piławska, Szkolna, Ceglana, Plac Kościelny - Firemen St, Bank St, Acaccia St, Railway St, Field St, Park St, New Bielawa St, Pilawa St, School St, Brick St, and Church Square). They were accepted probably because they were neutral. However, there is no street in

\footnotetext{
${ }^{32}$ K. Pludro, Kronika Bielawy. Od czasów najdawniejszych ..., p. 216.

${ }^{33}$ R. Brzeziński, Życie w dawnej Bielawie..., p. 187.
} 
Bielawa whose patron would represent the social life and modernisation processes of the pre-war town. In this symbolic space, even after 1990, no attempts were made to re-establish any broken cultural or civilisational bonds with the former inhabitants, in spite of taking over all their economic achievements. The newest plans, however, for the purpose of tourism, inform in four languages (Polish, German, English, and Czech) about the chief monuments in Bielawa, mostly from before 1945 (the residence of the former estate owners, churches, villas of factory owners, town symbols, tourist facilities, etc.). It is also worth noticing that street names on the current plaques are written in two languages, Polish and Czech.

\section{LITERARY TRACES}

The awareness of the transformations in the Polish-Czech-German borderlands in the generation born and raised in Lower Silesia is clearly present in the book by Hubert Dobrzaniecki, b. 1965, West Bielawa Station. ${ }^{34}$ This collection of biographical essays well represents the state of the local historical consciousness. The author is not a professional writer, who manipulates fiction for a living, but a gifted amateur who self-publishes his works. He gave a literary form to his thoughts about 'his borderlands'. The stories are set in the topographic and social realities of the Bielawa of his childhood and early youth. He refers his interpretations to the local community, with which he still feels connected, although some of his views about historical events are more general.

The author speaks with some respect about the former masters of Bielawa; for, in his memoirs, someone "who managed to become German" wos worthy of envy. ${ }^{35}$ Still, he reproduces a certain distance of the local community towards the past, nociting that in 1977 "the dwindling handful of Germans handed their church to the Catholics. (...) Nobody wanted to bury their dead in a German cemetery. For how could you lay the mortal remains of Kowalskis and Nowaks between Grubers, Meiers, Kuntzs and others. People like to remember, even after death. A Kowalski would much prefer to lie besides a Milopoulos, Bojko, or Petrescu than one of the former owners of the town. What if they come back one day and dig you up? Where would he lie, awaiting the Last Judgement? A German is a German, and the others are already here." ${ }^{36}$ This literary observation shows the aversion of the current inhabitants of Bielawa to its former dwellers. As a result, "German graves were overgrown with grass, headstone

\footnotetext{
${ }^{34}$ H. Dobrzaniecki, Stacja Bielawa Zachodnia [West Bielawa Station], Nowa Ruda 2003.

${ }^{35}$ H. Dobrzaniecki, Stacja Bielawa Zachodnia [West Bielawa Station], Nowa Ruda 2003, p. 19.

${ }^{36}$ H. Dobrzaniecki, Stacja Bielawa Zachodnia [West Bielawa Station], Nowa Ruda 2003, p. 57.
} 
inscriptions blurred, by night people carried away marble slabs, drunkards peed wherever they could, trees were dying, and nobody wanted to care for it. The town decided to raze the cemetery. It did not take long, and a park took the place of the cemetery. The better-looking trees were preserved, graves were replaced by lawns and pansies, and some benches were added. People did not like the change of cemetery into park, so they avoided it. Where there was an abandoned cemetery once, we now had an abandoned park." 37 Changing the function of this space did not affect the suppression from memory of the people buried there and their history.

The so-called Owl Mountains Railway is an important local site of memory. In his metaphorical description, Dobrzaniecki reminisced that "It stopped at the Bielawa Dolna station. It took a few people on there, looking with regret at the empty platform, which used to boil with travellers in the German times." ${ }^{38}$ And, on the West Bielawa station: "what was the purpose of two platforms, if the train returned the same way, on the same track, it must have remained from the German times, when the railway was full of life, was something very important in the life of such towns, and thousands of travellers went by train." ${ }^{39}$ The writer sees the German past as organisation - and civilisation-wise greater than the current reality surrounding him. He wrote with nostalgia on the symbol of his heritage, the Owl Mountains Railway, "there are locations on the world map which become ends of the world. Rails, once full of din, now end in an open field, which grows over more and more." 40

The author is quite averse, however, to the shaping of local post-war landscape by obscuring the past. "It all occurred during one long summer, decreed by some idiot who wanted to make aspecial demonstration of centuries-long Polish rule in the western territories. Another idiot erected a granite pillar in a well-visible place, bearing the words "We were, are, will be", nailed a crownless eagle over the slogan, brazenly ignoring everyone who was here before us and writing a fake history of the place where nobody spoke Polish for five hundred years. The place which remembered Bolko II the Small, Czech kings, Austrian emperors, Prussian and German rulers. And noone wanted to remember the truth of this place, just some people may have wondered why the luxury coaches stopping by the hotel were so persistent. Why these foreign people in white loafers and feathered hats were strolling through the town. They usually looked for something at the cemetery, brushing thickets aside and poking grass with some sticks. Their cemetery was an abandoned park now. ${ }^{\prime 41}$ For the author who matured

\footnotetext{
${ }^{37}$ H. Dobrzaniecki, Stacja Bielawa Zachodnia [West Bielawa Station], Nowa Ruda 2003, p. 60.

${ }^{38}$ H. Dobrzaniecki, Stacja Bielawa Zachodnia [West Bielawa Station], Nowa Ruda 2003, p. 73.

${ }^{39}$ H. Dobrzaniecki, Stacja Bielawa Zachodnia [West Bielawa Station], Nowa Ruda 2003, p. 74.

${ }^{40}$ H. Dobrzaniecki, Stacja Bielawa Zachodnia [West Bielawa Station], Nowa Ruda 2003, p. 94.

${ }^{41}$ H. Dobrzaniecki, Stacja Bielawa Zachodnia [West Bielawa Station], Nowa Ruda 2003, p. 76.
} 
in the latter half of the 1980s, the suppression of the memory of the German inhabitants of Bielawa was not acceptable any more. His regional heritage was not limited to the Polish settlement after 1945. He calls for the "truth of this place" with regard to the previous epochs as well. It is a significant change in the approach to the past.

Dobrzaniecki's prose also bears the mark of the events on the Polish-Czech border in 1938-1945. As he sees it, "after the war, the authorities of Czechoslovakia (...) treated the indigenous Poles very harshly. (...) to end once and for all the Polish rule over these areas, they began settling Silesia with people from Moravia and Slovakia. In a short time, less than half of the population of Zaolzie were Poles. (...) Poles became second-class citizens in Cieszyn Silesia, equals to the Gypsies from Slovakia. Matura (high-school graduation exam - AP) was the highest education a Pole could achieve. You could well forget about studies." ${ }^{\text {"2 }}$ Therefore, some "decided to go West, to the so-called Recovered Territories. They left for the old Piast Silesia, the land of Bolko II the Small and other Polish rulers, who valiantly repelled German raids for centuries. (...) Yet, besides this pack of lies and slogans, one thing was sure: they gave houses in the West, farms, flats, all for free!" 43 The author notices the longing of the emigrants from Cieszyn, invoking their concerns and hopes. He cited a rumour popular after the war: "Some secret negotiations are going on between Poles and Czechs. There're Czech soldiers in the mountains, even some important general has arrived. They want to exchange Cieszyn Silesia without Karviná for the Kłodzko Land, Nowa Ruda, Wałbrzych. To move the border beyond the mountains, beyond Jodłownik. The Czechs are not stupid, they wouldn't make such offers if the coal deposits were poorer than in Silesia".4 ${ }^{4}$ One of the characters in the book wrote on his headstone: "Here I lie, I left my heart there. Cieszyn-Bielawa." 45

Invoking views he heard and defining attitudes he observed, Dobrzaniecki does not shy away from describing the meagre knowledge of the borderlands he and his generation had. He wrote: "It was a different world beyond the mountains. The world of sugared peanuts, the world of good beer. The world of seemingly happy people speaking a language akin to ours, confessing not in churches but in inns, full of singing and clean as shrines to martyrs. Seemingly happy, because they only needed a different end to the events in Prague to be really happy. Now, they lived in the shadow of ubiquitous Soviet signs. They could be found on New-Year lanterns as well as locomotives. Even the proud Czech lion could not be free of the star hanging above his head: he too

\footnotetext{
${ }^{42}$ H. Dobrzaniecki, Stacja Bielawa Zachodnia [West Bielawa Station], Nowa Ruda 2003, p. 109.

${ }^{43}$ H. Dobrzaniecki, Stacja Bielawa Zachodnia [West Bielawa Station], Nowa Ruda 2003, p. 109.

${ }^{44}$ H. Dobrzaniecki, Stacja Bielawa Zachodnia [West Bielawa Station], Nowa Ruda 2003, p. 111.

${ }^{45}$ H. Dobrzaniecki, Stacja Bielawa Zachodnia [West Bielawa Station], Nowa Ruda 2003, p. 113.
} 
could not forget who ruled over him. Two nations, living so close together, so closely related, and so much divided historically by foreign rule and culture. They had to wait six centuries to be divided a common border again, now even more divided within the Socialist friendship. (...) And so we lived on both sides of the mountains, knowing little about one another. The Czechs drowned their problems in tankars of beer, the Poles solved theirs with a bottle of vodka and two shot glasses. The mountains stood still, observing the deepening division with calm. Sometimes someone managed to get an invitation or a year's contract in a shoes factory and then returned with news, kilograms of arašid nuts, and beer. Empty bottles of Opat, Primator, and other Czech beers were set atop kitchen cupboards besides religious items brought from pilgrimages to Częstochowa. Sometimes you could hear Czech imitations of Western hits sung by the divine Karel or catch the evening cartoons with the Tales of moss and fern. It was virtually all I knew about our neighbours. ${ }^{\prime 46}$ The author's imagination of the nearby town of Broumov "was but an image repeating the known nooks and corners of bigger and smaller towns in Lower Silesia. My Broumov combined Bielawa, Dzierżoniów, Pieszyce, Nowa Ruda, Świdnica, Ząbkowice Śląskie, and - Skawina. (...) This product of my imagination had the Dzierżoniów market square, town hall from Ząbkowice, streets of Bielawa, slag heaps of Nowa Ruda, church from Świdnica, and cemetary from Skawina. I later put the swimming pool from Pieszyce into this view. And so my 'Broumov' was complete." 47

The knowledge of the neighbours, constructed from the random pieces of information, related very little to the memory of the Czech culture in the borderlands, nor was it burdened with concerns and historical policy to such extent as it was in relation to the former German dwellers of the region. Which may be why it did not occupy an important place in the memory of people living in the foothills of Owl Mountains, who in the first decades were busy building their basic existence and concerned about its uncertainty.

However, the awareness of the borderland and its cultural role is clear in this author, as is his conviction that he belongs there. From the literary perspective of the early 21 st century, the author of West Bielawa sees the traits of consciousness of the community in his "small homeland". As well as the sites of memory of both the German and Czech heritages. Still, it is a reflection formed after the breakthrough of the 1990s, which changed how the past is viewed both from the perspective of local communities and national historical policy. The uncertain existence in the Recovered Territories and the policies of the state, typical of the earlier period, were still not conducive to

\footnotetext{
${ }^{46}$ H. Dobrzaniecki, Stacja Bielawa Zachodnia [West Bielawa Station], Nowa Ruda 2003, p. 117.

${ }^{47}$ H. Dobrzaniecki, Stacja Bielawa Zachodnia [West Bielawa Station], Nowa Ruda 2003, p. 118.
} 
reflection over the many historical layers in the Owl Mountains area, which could be the source to creating local 'memory sites' of its own heritage.

For the texts also reveal the concerns of the settlers of the time. "He was doing well, but in the early 1970s some strange men in dusters and feathered hats started visiting him. They came with an interpreter from Wroclaw, saying that if he continued to care for their farm so well, he would be allowed to work for them when they come back." ${ }^{48}$ The author feels he is a borderlander: "In fifty years, what are we going to be? And the world? Who shall write the rest of this story of borderlands? Will it even exist... Panta rhei, as the Greeks said, the ancient and those from Bielawa too." 49

The Czech presence can also be found in literature. This area of cultural borderlands is represented by Reinmar von Bielau's Lower Silesian and Czech adventures: A Hussite trilogy by Andrzej Sapkowski, written in the popular convention of historical fantasy. It strongly influences the common social awareness without presenting the views of regionalists.

\section{SITES OF LOCAL MEMORY IN THE VIEWS OF REG1ONALISTS}

After 1990, the "unwanted heritage" became the object of considerations of regionalists, both professionals with historical background and, or perhaps most of all, the enthusiasts of the history of their mini-region. They are usually local history enthusiasts, authors of popular texts, various cultural activists, and sightseers rather than professional historians. Still, the region began to play an increasingly significant role in professional historical research as well. The changes in the attitude of the local community to the interpretation of cultural heritage as well as historiographic trends supporting and permeating them created a mood conducive of interest in the achievements of the dwellers of these lands before 1945. The topic of the German cultural heritage in Lower Silesia became a legitimate field of study and historical interest, and some 'sites of memory' related to it were invoked from the doomed-to-oblivion area. The sentence of the authors of historical policies from the early post-war years was no longer accepted. What is more, it led the authors who were born in this land to objections, regret, and a conviction that the 'blank gaps' needed to be filled. ${ }^{50}$

The generation born under the Owl Mountains was looking for the sources of its own regional identity, crossing the border of 1945 . Declarations revealing the awareness

\footnotetext{
${ }^{48}$ H. Dobrzaniecki, Stacja Bielawa Zachodnia [West Bielawa Station], Nowa Ruda 2003, p. 128.

${ }^{49}$ H. Dobrzaniecki, Stacja Bielawa Zachodnia [West Bielawa Station], Nowa Ruda 2003, p. 133.

${ }^{50}$ See: R.M. Łuczyński, Tropami śląskiego dziedzictwa [Tracking the Silesian heritage], Wrocław 2000.
} 
of the consequences of this broken continuity in the perception of the region's heritage can also be found in the works devoted to the Owl Mountains region. They flitted through the Chronicles of Bielawa by Krzysztof Pludra, and can be found in the work In the shadow of Great Owl. Monograph of the Owl Mountains, a collective work edited by T. Przerwa and T. Śnieżek (Dzierżoniów 2006). The dates of some such publications are conscious references to past events. For instane, the one mentioned above is the 100th anniversary of the observation tower on Great Owl, initially dedicated to Bismarck. Components of material and spiritual culture are recalled, illustrious representatives of German culture connected with the Owl Mountains area (e.g., the great controversial theologian Josef Wittig), and the activities for the protection of broadly understood regional heritage connected with the "home country protection movement' in the late 19th century. Its ideologist Ernst Rudorff identified landscape with indigenous nature and culture, stressing its patriotic value. ${ }^{51}$ The Polish authors also notice the large number of works on this topic.

Tomasz Śnieżek, a guide, sightseer, and local government activst, interprets the issue of the perception of cultural heritage after 1945 in a way representative of such attitudes: "Political pressure, war trauma, population exchante, and being cut off by the 'iron curtain' changed the cultural life of the Owl Mountains area. The Poles who came after 1945 began writing a new chapter in the history of the region's culture, isolated from the forbidden heritage of the previous inhabitants. They domesticated the space and enriched it with their activities. New patterns and traditions emerged, helping the settlers to identify themselves with the area. In the recent years, the normalisation of political life and opening of borders facilitated the contacts with the former, German, inhabitants of the Owl Mountains and broadened the interest in the past and the prior culture of the Owl Mountains region. An unterstanding and a need to continue the broken heritage are slowly emerging." 52

In this context, external factors seem responsible for creating the perspectives of interpretation of local cultural heritage in the so-called Recovered Territories, stimulating attitudes towards the sites of memory of the local population. Regionalists clearly see the break in the cultural and civilisational continuity. They also notice that the cultural mosaic composed of the separate worlds of views and values of people from various regions of Poland as well as the former Kresy, Romania, France, and immigrants from Greece, was not conducive of any interest in the heritage of the former

\footnotetext{
${ }^{51}$ W cieniu Wielkiej Sowy: Monografia Gór Sowich [In the shadow of Great Owl: Monograph], ed. by T. Przerwa \& T. Śnieżek, Dzierżoniów 2006, p. 70-114.

${ }^{52}$ T. Śnieżek, "Kontynuacja czy nowe otwarcie" [Continuation or new opening], in: $W$ cieniu Wielkiej Sowy: Monografia..., p. 107.
} 
inhabitants of the area. The state policy, in turn, was directed at shaping the traits of national culture, which did not promote cultivating diversity or interest in objects of German culture. The Owl Mountains regionalists stressed, however, that this cultural mosaic caused the need of multilateral adaptation, which led to a greater openness towards "others" in the region. They also mention that because of it the culture of the Owl Mountains communities is mostly imported and lacks indigenous components. ${ }^{53}$

The process of "eradicating previous heritage" is sometimes considered as natural by the local historians; new settlers, who arrived in the land unknown to them, tried to take it over, helped by the state policy. The polonisation of the local names was part of this process. As the reginalists remark, it served the domestication of the area as well as covering previous German cultural influences. Some names were translations (Srebrna Góra, Góry Sowie), some were entirely new. With time, some former names were adapted in peculiar ways (the Park Mountain in Bielawa, once Herreleinberg, commonly: Holimberek). The process of waking the local consciousness is placed after 1989, quoting the difficulties of shedding the bonds of thinking in terms of Piasts about these lands. In consequence, a number of local initiatives were born, e.g., for landscape protection or museums. The regionalists see the 1970s, and 1990s in particular, as the time of breakthrough in Polish-German relations, which enabled closer contacts and verification of mutual myths and stereotypes. It promotes invoking the forgotten sites of memory. In Bielawa, it was the joint celebration of the 160th anniversary of the Silesian Weavers' Uprising in 2004.

Here is how the chronicler of Bielawa sees this process: "with the evacuation of the German population of Bielawa, an important chapter in the town's history has ended definitely, a chapter which cannot, must not be crossed out, passed over, or glossed over in any way. For we (...) inherit not just torn out fragments but the whole continuity of existence of the people who once inhabited this strip of land. Including those who spoke a different language than we do. Simply because their history is now part of our history. The principle of preserving historical continuity, ability to observe tradition, the collective achievements of human communities, amassed over centuries and constantly enriched with creative work, all that is comprised in the notion of 'culture' which remains one and indivisible with all its diversity. So what if we read the name Langenbielau in the old documents of Bielawa. Such was the history of the land, which we should absorb. We have to admit into our historical awareness the truth that, 100, 200 years ago and earlier, Bielawa was inhabited by normal people like us. They walked the same streets we do today, lived in many

${ }^{53}$ W. Rychel, "Powojenne życie kulturalne: Centra życia kulturalnego" [Post-war cultural life], in: $W$ cieniu Wielkiej Sowy: Monografia..., p. 108-110. 
houses, now our homes. They lived, learned, played, loved, and fell ill here. As fates dictated, they were born, grew up, and died. Fates made them leave this place without hope and right to return. They deserve neither our collective condemnation or oblivion. They left a tradition of enormous prudent industriousness, persistence, and determination with which they rebuilt their village from ruins and fall after each calamity, the tradition of connection to and love of the nearest home country, seen through the windows of family home. ${ }^{24}$

The review of key issues connected with the meanings given to the events of the past, forgetting or suppressing some of them from memory, or using them instrumentally combines into an interesting mosaic of strategies of shaping sites of memory. One of the most permanent ones, always present, first used instrumentally for ideological, then for marketing reasons, is the riot of the weavers form the Owl Mountains and its reflection in the prose of G. Hauptmann. The range of possibilities to create local sites of memory based on the past before 1945 has somewhat grown with the improvement of Polish-German relations in the 1970s and the 'sentimental voyages' of the old dwellers of Bielawa to the town. After 1990 there was a breakthrough, as the historical policy of the state, which doomed all non-Polish heritage of the so-called Recovered Territories to oblivion was no longer valid. The "unwanted heritage" became the object of studies of regionalists. However, there are no symbolical references to the German culture in the urban space of Bielawa. They only exist, to a limited extent, in relation to the regional space, they do not emphasise the ethnicity of the former inhabitants but their civilisational achievements shaping the cultural landscape. The railway and industrial relics gradually dilapidated once they lost their economic functions without gaining the status of heritage of material culture among the local community. This process intensified at the turn of the 21 st century.

Marketing actions promoting the tourism values of the Owl Mountains usually broadly refer to their multicultural civilisational achievements. Whereas regional education reaches into the past and stresses the formation process of the homogeneous Polish community in the pioneering period of the late 1940s. In the changed systemic, social, and political conditions, the German and Czech heritage of the borderlands became the area to seek the sources and write regional history, sometimes literature. In the local sites of memory, however, the national take of the old heritage is rare. The marketing processes in the micro-region promote its ecological character and tourism, where the past is treated instrumentally as an attraction, is not conducive to it. A view designed so required a departure from the image of Bielawa historically

${ }^{54}$ K. Pludro, Kronika Bielawy. Od czasów najdawniejszych ..., p. 274. 
and economically dominated by weaving and textile industry, which ceased to exist in 2008. That is, from the essence of the history of Bielawa so far. What remains in the narration of the past, also that designed for tourists, is mainly the weavers' riot and Hauptmann's drama. The undertaken studies into the past, unlimited by politics, now use the regional perspective. However, they involve few researchers and regionalistsamateurs. Some chosen parts of this perception of the past find their way to the local view of the development of the town and the Owl Mountains micro-region. Nonetheless, it does not create favourable conditions for shaping sites of memory devoted to the community who lived here before 1945 , albeit for completely different reasons than in 1945-1989.

\section{TRANSLATION: AndrZej PIETKIEWICZ}

\section{BIBLIOGRAPHY.}

Bielawa, (online), dostęp: 10 marca 2015. [strona WWW] http://www.bielawa.net.pl.

Biblioteca Bielaviana, (online), dostęp: 10 grudnia 2014. [strona WWW]: [strona WWW] http://bibliothecabielaviana.com

[strona WWW] http://mbp.bielawa.pl.

Brzeziński R., Życie w dawnej Bielawie, Ludzie, miejsca, wydarzenia, Wrocław 2008.

Dobrzaniecki H., Stacja Bielawa Zachodnia [West Bielawa Station], Nowa Ruda 2003.

Gimanzjum Publiczne w Głuszycy, (online), dostęp: 10 marca 2015. [strona WWW]: http://www.gimgluszyca.cba.pl/index.php?option=com_content\&view=article\&id=322:dzie dzictwo-kulturowe-gor-sowich\&catid=34:newsy.

Hotel Dębowy, (online), dostęp: 10 marca 2015. [strona WWW]: http://www.hoteldebowy.pl.

Krosno 1958, z. 14/15.

Mikos v. Rohrscheidt A., Raport: Analiza potencjału turystyczno-kulturowego powiatu dzierżoniowskiego (online) [Report: Analysis of the tourism and cultural potential of the Dzierżoniów County], dostęp: 05 maja 2015. [strona WWW]: Turystyka Kulturowa, 2013, 2, p. 69-85.

Łuczyński R.M., Tropami ślaskiego dziedzictwa [Tracking the Silesian heritage], Wrocław 2000.

Pludro K., Kronika Bielawy. Część V. Lata 1945-1990 [Chronicle of Bielawa: Part V: 1945-1990], Dzierżoniów 2002.

Pludro K., Kronika Bielawy. Od czasów najdawniejszych do $1945 r$. [Chronicle of Bielawa: From the earliest times to 1945], Dzierżoniów 2007.

Pludro K., Kronika Bielawy. Lata 1990-2004 [Chronicle of Bielawa: 1990-2004], Dzierżoniów 2005.

Stowarzyszenie Turystyczne Gór Sowich, (online), dostęp: 10 grudnia 2014. [strona WWW]: http://gorysowie.org.

Śnieżek T., Góry Sowie. Przewodnik, 2012.

Szynkiewicz A., Eulengebirgsbahn - czyli nierealne marzenie jakie zrealizowano, (online), dostęp: 25 marzec 2015. [strona WWW] : http://www.kolej.one.pl/ halski/linie/sowiogorska/eulen2.html.

W cieniu Wielkiej Sowy: Monografia Gór Sowich, pod red. Przerwy T. i Śnieżka T., [red.] T. Przerwa \& T. Śnieżek, Dzierżoniów 2006. 